Check for updates

Cite this: RSC Adv., 2019, 9, 23579

Received 31st May 2019

Accepted 24th July 2019

DOI: 10.1039/c9ra04127c

rsc.li/rsc-advances

\section{Ozone and ozone/vacuum-UV degradation of diethyl dithiocarbamate collector: kinetics, mineralization, byproducts and pathways $\uparrow$}

\author{
Pingfeng Fu, (D)* Yanhong Ma, Huifen Yang, Gen Li and Xiaofeng Lin
}

\begin{abstract}
The diethyl dithiocarbamate (DDC) collector, a precursor of toxic $N$-nitrosamines, is detected in flotation wastewaters usually at the ppm level. In this study, the $\mathrm{O}_{3}$ and $\mathrm{O}_{3} /$ Vacuum-UV $\left(\mathrm{O}_{3} / \mathrm{VUV}\right)$ processes were compared to investigate the efficient removal of DDC with a low risk of $\mathrm{N}$-nitrosamine formation. The results showed that $99.55 \%$ of DDC was removed at $20 \mathrm{~min}$ by $\mathrm{O}_{3} / \mathrm{VUV}$, and the degradation rate constant was 3.99 times higher than that using $\mathrm{O}_{3}$-alone. The $\mathrm{C}, \mathrm{S}$ and $\mathrm{N}$ mineralization extents of DDC using $\mathrm{O}_{3}$ /VUV reached $36.36 \%, 62.69 \%$ and $79.76 \%$ at $90 \mathrm{~min}$, respectively. $\mathrm{O}_{3} / \mathrm{VUV}$ achieved a much higher mineralization extent of DDC than $\mathrm{O}_{3}$-alone. After 90 min of degradation, $\mathrm{O}_{3} / \mathrm{VUV}$ achieved lower residual concentrations of $\mathrm{CS}_{2}$ and $\mathrm{H}_{2} \mathrm{~S}$, and released lower amounts of gaseous sulfur byproducts compared to $\mathrm{O}_{3}$-alone. The solid phase extraction and gas chromatography-mass spectrometry (SPE/ GC-MS) analysis indicated that the main byproducts in $\mathrm{O}_{3} / \mathrm{VUV}$ degradation of DDC were amide compounds without the detection of $\mathrm{N}$-nitrosamines. The avoidance of $\mathrm{N}$-nitrosamine formation might be attributed to exposure of UV irradiation and enhanced formation of $\cdot \mathrm{OH}$ radicals in the $\mathrm{O}_{3} / \mathrm{VUV}$ system. The degradation pathways of DDC were proposed. This work indicated that $\mathrm{O}_{3} / \mathrm{VUV}$ was an efficient alternative treatment technique for the removal of DDC flotation collector with low risk of $N$ nitrosamine formation.
\end{abstract}

\section{Introduction}

Diethyl dithiocarbamate (DDC), one of the widely used dithiocarbamates (DTCs), has a strong chelating capacity with metal species to generate insoluble and stable metallic complexes. ${ }^{1}$ Acting as a superior ligand, an extremely large quantity of DDC is used as a flotation collector in mining, as a fungicide in agriculture, and as a functional additive in rubber and lubricants. In the mining industry, to separate base metal sulfides or platinum minerals from ores, the DDC collector can react with mineral surfaces to render them hydrophobic, and subsequently to form stable particle-bubble agglomerates., ${ }^{2,3}$ In China, the DDC collector even gets a trivial name, SN-9, due to its wide usage in the separation of $\mathrm{Cu}-\mathrm{Fe}$ and $\mathrm{Pb}-\mathrm{Zn}$ minerals. ${ }^{\mathbf{4 , 5}}$ Owing to the ubiquitous applications of DDC in various fields, it has been frequently detected in surface water and municipal wastewater at the ppb level. ${ }^{6}$

It has been documented that DDC and its $N$-nitrosamine byproducts are extremely toxic to aquatic animals and human beings. For example, the hydrophobic metallic complexes of

School of Civil and Resources Engineering, University of Science and Technology Beijing, Beijing 100083, China. E-mail: pffu@ces.ustb.edu.cn; Fax: +86 10 82385795; Tel: +8613520202167

† Electronic supplementary information (ESI) available. See DOI: 10.1039/c9ra04127c
DDC can significantly increase the bioaccumulation of heavy metals in Daphnia magna and Rainbow trout. ${ }^{7,8}$ Moreover, DDC can even affect the biological behaviors of heavy metals accumulated within mice and rats. The metals such as nickel ${ }^{9}$ and mercury $^{\mathbf{1 0}}$ can be partly redistributed from traditional metal enriching organs to the brain and adipose tissue of mice. In addition, due to its instability in acidic medium, DDC can be hydrolyzed to diethylamine (DEA) with a rate constant of $9.2 \times$ $10^{-4} \mathrm{~s}^{-1}$ with a half-life of $0.2 \mathrm{~h}$ at $\mathrm{pH} 5 .{ }^{11}$ However, the hydrolysis rate constant of DDC may become as low as $1.0 \times$ $10^{-7} \mathrm{~s}^{-1}$ with a half-life of $1905.5 \mathrm{~h}$ at $\mathrm{pH} 9 .^{11}$ Subsequently, $N$ nitrosodiethylamine (NDEA) can be generated in drinking water while DEA is oxidized by water disinfection oxidants like $\mathrm{Cl}_{2}$ and $\mathrm{O}_{3} \cdot{ }^{11} \mathrm{NDEA}$ is a typical nitrogenous disinfection byproduct with probable cytotoxicity, genotoxicity and carcinogenesis. It has been included in the $3^{\text {rd }}$ version of the Contaminant Candidate List (CCL 3) of the US EPA for drinking water. Based on these facts, DDC is an important indirect precursor of toxic NDEA. Therefore, special attention should be paid for the removal of DDC and its $N$-nitrosamine byproducts from the aquatic system.

Currently, $N$-nitrosamines in drinking water and wastewater were of great concern. Some methods including advanced oxidation processes (AOPs), ${ }^{12}$ integrated membrane system ${ }^{\mathbf{1 3}}$ and nanoscale zero-valent iron, ${ }^{\mathbf{1 4}}$ have been developed to remove toxic NDEA. However, the information on how to 
remove NDEA's precursors such as DDC in aqueous solutions is very limited. This may be attributed to very low concentration (ppb level) of DDC in water because most of the DDC used as fungicides and additives are discharged with a fugitive emission mode. ${ }^{15}$ Nevertheless, the DDC concentration in the mineral flotation wastewaters is as high as ppm level, e.g., 10$100 \mathrm{mg} \mathrm{L}^{-1}$, because of the high dosage of DDC collector (30$200 \mathrm{~g} \mathrm{t}^{-1}$ (ore)) in mining industry. ${ }^{16,17}$ To avoid toxic effects of DDC collector to aquatic organisms and reduce the release of $\mathrm{N}$ nitrosamines into aquatic system, it is extremely necessary to remove DDC collector with ppm level before the mineral flotation wastewaters are discharged into rivers.

Recently, biodegradation, ${ }^{18,19}$ ozonation ${ }^{11,20}$ and chemical oxidation with hypochlorite ${ }^{\mathbf{2 1}}$ have been investigated to degrade DDC collector. Although the DDC can be removed by the biodegradation, the half-life of DDC biodegradation was as high as $36.96 \mathrm{~h}^{18}$ The chemical oxidation can rapidly decompose DDC. For instance, $91.28 \%$ removal of DDC was achieved even within 1 min using $400 \mathrm{mg} \mathrm{L}{ }^{-1}$ hypochlorite. ${ }^{21}$ However, it has been reported that the oxidation of DDC with free chlorine and hypochlorite can form $N$-nitrosamine byproducts. ${ }^{11}$ In our previous work, $100 \mathrm{mg} \mathrm{L}^{-1}$ of DDC solution was effectively decomposed by the ozonation with the half-life of $10.09 \mathrm{~min}^{20}$ Nevertheless, the formation of $\mathrm{N}$-nitrosamines is also observed in the ozonation of DDC. ${ }^{11}$ The degradation of NDEA by $\mathrm{O}_{3}$ alone is usually less effective with a second-rate constant of only $0.08 \mathrm{M}^{-1} \mathrm{~S}^{-1}$, much lower than that of $7 \times 10^{8} \mathrm{M}^{-1} \mathrm{~S}^{-1}$ by hydroxyl radicals ( $\left.{ }^{\circ} \mathrm{OH}\right) .{ }^{12,22}$ Thus, the combined processes such as the $\mathrm{O}_{3} / \mathrm{H}_{2} \mathrm{O}_{2}$ and $\mathrm{O}_{3} / \mathrm{UV}_{254 \mathrm{~nm}}$ have been developed to remove NDEA from aquatic system. ${ }^{12,23,24}$ Therefore, a novel process with a high yield of $\mathrm{OH}$ radicals can provide the benefits of effective removal of DDC collector with low risk of $\mathrm{N}$-nitrosamine formation.

In various AOPs, the $\mathrm{O}_{3} /$ vacuum-UV $\left(\mathrm{O}_{3} / \mathrm{VUV}\right)$ has the higher yield of ${ }^{\circ} \mathrm{OH}$ radicals than $\mathrm{O}_{3}, \mathrm{O}_{3} / \mathrm{UV}_{254 \mathrm{~nm}}$ and $\mathrm{O}_{3} / \mathrm{H}_{2} \mathrm{O}_{2}$ per mass of oxidants. ${ }^{25}$ The VUV lamp, namely, low pressure $\mathrm{Hg}$ lamp covered with high pure quartz glass, can emit about $10 \%$ radiation at $185 \mathrm{~nm}$ and $90 \%$ radiation at $254 \mathrm{~nm}$. In the $\mathrm{O}_{3} / \mathrm{VUV}$ system, the $185 \mathrm{~nm}$ VUV irradiation of water can in situ generate $\cdot \mathrm{OH}$ radicals (eqn (1) and (2)). By combining $\mathrm{UV}_{254 \mathrm{~nm}}$ light emitted from VUV lamp and dosed $\mathrm{O}_{3}$, the $\mathrm{O}_{3} / \mathrm{UV}_{254 \mathrm{~nm}}$ can be formed with the generation of ${ }^{\circ} \mathrm{OH}$ radicals via eqn (3)-(5). Therefore, three oxidation processes, i.e., VUV photolysis, $\mathrm{O}_{3} /$ $\mathrm{UV}_{254 \mathrm{~nm}}$ and ozonation, may be included in the $\mathrm{O}_{3} / \mathrm{VUV}$ system. ${ }^{26}$ Thus, previous studies had demonstrated that the $\mathrm{O}_{3} /$ VUV could achieve much higher removal efficiencies of $n$-butyl xanthate, ${ }^{24}$ natural organic matter ${ }^{27}$ and phenols ${ }^{28}$ than $\mathrm{O}_{3}$ alone. For the degradation of $N$-nitrosamines, simple $\mathrm{UV}_{254 \mathrm{~nm}}$ photolysis can remove $N$-nitrosamines effectively due to their strong UV absorption..$^{29,30}$ Therefore, it can be expected that the degradation of DDC by the $\mathrm{O}_{3} / \mathrm{VUV}$ would achieve higher removal of DDC with low risk of $N$-nitrosamine formation than $\mathrm{O}_{3}$-alone.

$$
\begin{gathered}
\mathrm{H}_{2} \mathrm{O}+h \nu_{185 \mathrm{~nm}} \rightarrow \cdot \mathrm{OH}+{ }^{\cdot} \mathrm{H} \\
\mathrm{H}_{2} \mathrm{O}+h \nu_{185 \mathrm{~nm}} \rightarrow \cdot \mathrm{OH}+\mathrm{H}^{+}+\mathrm{e}_{\mathrm{eq}}{ }^{-}
\end{gathered}
$$

$$
\begin{gathered}
\mathrm{O}_{3}+\mathrm{H}_{2} \mathrm{O}+h \nu_{254 \mathrm{~nm}} \rightarrow \mathrm{H}_{2} \mathrm{O}_{2}+\mathrm{O}_{2} \\
\mathrm{H}_{2} \mathrm{O}_{2}+2 \mathrm{O}_{3} \rightarrow 2^{\cdot} \mathrm{OH}+3 \mathrm{O}_{2} \\
\mathrm{H}_{2} \mathrm{O}_{2}+h \nu_{254 \mathrm{~nm}} \rightarrow 2^{\circ} \mathrm{OH}
\end{gathered}
$$

In this study, the degradation of DDC collector at initial concentration of $100 \mathrm{mg} \mathrm{L}^{-1}$ is compared by the $\mathrm{O}_{3}$ and $\mathrm{O}_{3} / \mathrm{VUV}$ at low $\mathrm{O}_{3}$ dosage of below $1.27 \mathrm{mg} \mathrm{min}^{-1} \mathrm{~L}^{-1}$. The objectives of this work are (1) to compare the removal efficiencies and mineralization extents of DDC by the $\mathrm{O}_{3}$ and $\mathrm{O}_{3} / \mathrm{VUV} ;(2)$ to investigate the generation of $\mathrm{CS}_{2}$ and $\mathrm{H}_{2} \mathrm{~S}$ byproducts; (3) to identify organic byproducts and propose degradation pathways of DDC. This work may be helpful to explore a method to effectively remove DDC collector from mineral flotation wastewaters.

\section{Materials and methods}

\subsection{Chemicals and VUV lamp}

Sodium diethyl dithiocarbamate trihydrate $\left(\mathrm{C}_{5} \mathrm{H}_{10} \mathrm{NS}_{2} \mathrm{Na} \cdot 3 \mathrm{H}_{2} \mathrm{O}\right)$ with analytical grade was purchased from Shanghai Aladdin Bio-Chem Technology Co., Ltd, China. Fig. S1 (see in the ESI $\dagger$ ) shows the molecular structure of DDC. Other chemicals such as cupric acetate, lead acetate, diethylamine, silver sulfate and mercury sulfate were of analytical grade and purchased from Sinopharm Chemical Reagent Co., Ltd, Beijing, China. Deionized water was used in the degradation experiments. A $40 \mathrm{~W}$ VUV lamp was purchased from Bright Star Light \& Electricity Co., Ltd, Guangdong, China. The lamp emitted about $10 \%$ of $185 \mathrm{~nm}$ VUV radiation and $90 \%$ of $\mathrm{UV}_{254 \mathrm{~nm}}$ radiation (see in Fig. S2 $\dagger$ ). To conduct the $\mathrm{O}_{3} / \mathrm{UV}_{254 \mathrm{~nm}}$ and $\mathrm{UV}_{254 \mathrm{~nm}}$ photolysis experiments, the $\mathrm{UV}_{254 \mathrm{~nm}}$ lamp, with same electric power and size to the VUV lamp, was purchased.

\subsection{The degradation procedures}

The DDC degradation was conducted in a jacket glass reactor connected with a thermostatic bath. Fig. 1 showed the schematic diagram of experimental setup. The cylindrical reactor had a $1240 \mathrm{~mm}$ height and $53 \mathrm{~mm}$ internal diameter. The VUV or $\mathrm{UV}_{254 \mathrm{~nm}}$ lamp was inserted into a quartz tube installed at the axis of the reactor. Ozone was generated from an $\mathrm{O}_{3}$ generator (SW-004 model, Qingdao West Electronic Purifiers Co., Qingdao, China) using air as the source. The $\mathrm{O}_{3}$ stream was introduced into the reactor through a porous glass plate.

$100 \mathrm{mg} \mathrm{L}^{-1}$ of DDC solution was prepared by dissolving $0.265 \mathrm{~g}$ DDC with trihydrate in $2 \mathrm{~L}$ deionized water. The initial $\mathrm{pH}$ was adjusted to 10.0 using $0.05 \mathrm{~mol} \mathrm{~L}^{-1} \mathrm{NaOH}$ or $\mathrm{HCl}$ solution. While $2 \mathrm{~L}$ of DDC solution was put into the reactor, the ozonation of DDC was conducted by introducing the $\mathrm{O}_{3}$ stream. The $\mathrm{O}_{3} / \mathrm{VUV}$ and $\mathrm{O}_{3} / \mathrm{UV}_{254 \mathrm{~nm}}$ degradation of DDC was performed by introducing $\mathrm{O}_{3}$ stream and turning on the VUV and $\mathrm{UV}_{254 \mathrm{~nm}}$ lamps, respectively. The $\mathrm{O}_{3}$ dosage rate was controlled to be $0.62-1.27 \mathrm{mg} \mathrm{min}^{-1} \mathrm{~L}^{-1}$. To perform the VUV and $\mathrm{UV}_{254 \mathrm{~nm}}$ photolysis of DDC, an air stream was introduced at a flow rate of $1.67 \mathrm{~L} \mathrm{~min}^{-1}$, and the VUV and $\mathrm{UV}_{254 \mathrm{~nm}}$ lamps were simultaneously turned on, respectively. In this study, the $\mathrm{O}_{3} / \mathrm{UV}_{254 \mathrm{~nm}}$, 


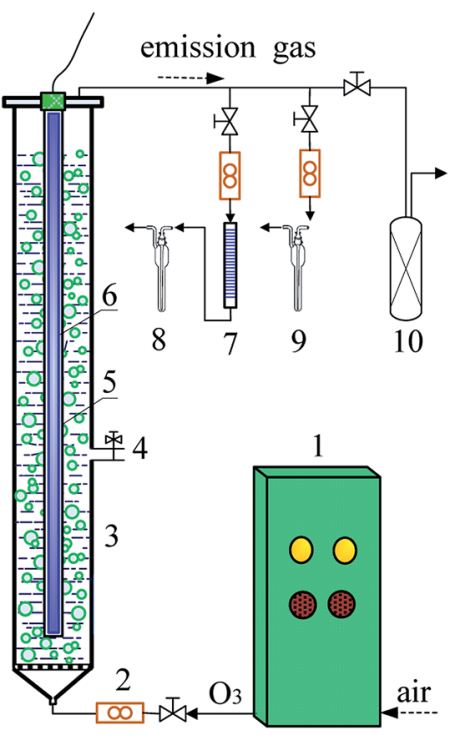

Fig. 1 Schematic diagram of experimental setup ((1) ozone generator; (2) flow meter; (3) column reactor; (4) sampling valve; (5) quartz tube; (6) VUV lamp; (7) absorbent cotton with lead acetate; (8) $\mathrm{CS}_{2}$ absorption liquid; (9) $\mathrm{H}_{2} \mathrm{~S}$ absorption liquid; (10) activated carbon column)

VUV photolysis and $\mathrm{UV}_{254 \mathrm{~nm}}$ photolysis experiments were performed for the comparative purposes. To fully evaluate the mineralization of DDC, the degradation time was extended to 90 min although nearly $100 \%$ of DDC could be removed within $20 \mathrm{~min}$. All experiments were conducted at $25 \pm 2{ }^{\circ} \mathrm{C}$. Aqueous samples were taken at predetermined time intervals to measure the concentrations of DDC, TOC, $\mathrm{SO}_{4}{ }^{2-}$ and $\mathrm{NO}_{3}{ }^{-}$anions, respectively.

\subsection{Analysis and calculation}

2.3.1 Determination of the concentrations of DDC, TOC, $\mathrm{SO}_{4}{ }^{2-}$ and $\mathrm{NO}_{3}{ }^{-}$ions. The concentration of DDC was determined by a UV-vis spectroscopic method since the DDC had a maximum absorption peak at $256 \mathrm{~nm}$. The absorbance of aqueous samples was recorded at $256 \mathrm{~nm}$ by a UV-vis spectrophotometer (UV-5500PC, Shanghai Metash Instruments Co. Ltd, China). The TOC was measured using a Shimadzu TOC-V organic carbon analyzer.

The $\mathrm{SO}_{4}{ }^{2-}$ concentration was analyzed by a barium chromate spectrophotometry method (HJ/T 342-2007). The $\mathrm{NO}_{3}{ }^{-}$ concentration was determined by using an ion chromatograph (Metrohm 792 Basic, Switzerland). Anionic species were separated by a Star-Ion A300 anionic column using a carbonate eluting phase consisted of $2.4 \mathrm{mmol} \mathrm{L}^{-1} \mathrm{NaHCO}_{3}$ and $2.5 \mathrm{mmol}$

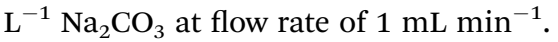

2.3.2 Analysis of the concentrations of aqueous $\mathrm{CS}_{2}$ and $\mathrm{H}_{2} \mathrm{~S}$. The aqueous $\mathrm{CS}_{2}$ concentration was measured by a diethylamine cupric acetate spectrophotometric method (GB/T 15504-1995). $50 \mathrm{~mL}$ of aqueous sample was purged with a 100 $\mathrm{mL} \min ^{-1} \mathrm{~N}_{2}$ stream for $1 \mathrm{~h}$ to volatilize $\mathrm{CS}_{2}$ which was subsequently absorbed with a diethylamine and cupric acetate mixed liquid. Then, the absorbance of $\mathrm{CS}_{2}$ absorption liquid was determined at $430 \mathrm{~nm}$ using dehydrated alcohol as a reference solution. The aqueous $\mathrm{H}_{2} \mathrm{~S}$ concentration was determined by an iodometric method (HJ/T 60-2000). The sulfides in the treated DDC solution should be transformed into $\mathrm{ZnS}$ by adding $\mathrm{Zn}\left(\mathrm{CH}_{3}(\mathrm{COO})_{2}\right)$ and $\mathrm{NaOH}$ solution before the analysis.

2.3.3 Measurement of the amount of gaseous $\mathrm{CS}_{2}$ and $\mathrm{H}_{2} \mathrm{~S}$ emitted into air. The amount of gaseous $\mathrm{CS}_{2}$ emitted into air was measured by a diethylamine spectrophotometric method (GB/T 14680-93). As shown in Fig. 1, the emission gas was allowed to pass through a lead acetate coated cotton tube to remove the $\mathrm{H}_{2} \mathrm{~S}$, and then introduced into the $\mathrm{CS}_{2}$ absorption liquid. The amount of gaseous $\mathrm{H}_{2} \mathrm{~S}$ was determined by a methylene blue spectrophotometric method (GB/T 11742-89). To collect all of gaseous $\mathrm{CS}_{2}$ and $\mathrm{H}_{2} \mathrm{~S}$, the emission gas continuously passed through the $\mathrm{CS}_{2}$ and $\mathrm{H}_{2} \mathrm{~S}$ absorption liquid for 90 min, respectively.

2.3.4 SPE/GC-MS analysis of organic byproducts. The solid phase extraction and gas chromatography-mass spectrometry (SPE/GC-MS) was developed to determine organic byproducts in the $\mathrm{O}_{3} / \mathrm{VUV}$ degradation of DDC. The SPE 24-port vacuum manifold system (Phenomenex, U.S.) was used to extract byproducts from water. The Strata ${ }^{\mathrm{TM}}-\mathrm{X}(10 \mathrm{~g}$, code: $8 \mathrm{~B}-\mathrm{S029}$ MFF, Phenomenex) was employed as the SPE sorbent. Firstly, the SPE cartridges were preconditioned with $2 \mathrm{~mL}$ of acetonitrile, followed by $1 \mathrm{~mL}$ of ultrapure water. Afterwards, $50 \mathrm{~mL}$ of acidified samples were allowed to pass through the cartridges at a flow rate of $3 \mathrm{~mL} \mathrm{~min}{ }^{-1}$. Then, the cartridges were rinsed with $5 \mathrm{~mL}$ ultrapure water, and further dried under vacuum for $10 \mathrm{~min}$ to removal residual water. The analytes were eluted with $3 \mathrm{~mL}$ of acetonitrile. The organic extracts were transferred into $300 \mu \mathrm{L} \mathrm{GC}$ vials for analysis.

The SPE extracts were analyzed by the GC-MS (Shimadzu, GCMS-QP2010 SE, Japan), equipped with a capillary column (Zebron ZB-FFAP, $30 \mathrm{~m} \times 0.32 \mathrm{~mm} \times 0.25 \mu \mathrm{m}$, Phenomenex, U.S.). The oven temperature program was as follow: an initial oven temperature was $80^{\circ} \mathrm{C}$ (held for $5 \mathrm{~min}$ ), then increased to $220^{\circ} \mathrm{C}$ (held for $10 \mathrm{~min}$ ) at $8{ }^{\circ} \mathrm{C} \mathrm{min}^{-1}$, and finally increased to $300{ }^{\circ} \mathrm{C}$ (held for $1 \mathrm{~min}$ ) at $30{ }^{\circ} \mathrm{C} \mathrm{min}^{-1}$. High purity He gas (purity $\geq 99.999 \%$ ) was used as carrier gas at flow rate of 1 $\mathrm{mL} \mathrm{min}^{-1}$. The ion source of mass spectra was operated in the electron impact mode (EI mode, electron energy $70 \mathrm{eV}, 220^{\circ} \mathrm{C}$ ). Full-scan mass $(m / z 40-500)$ was recorded to identify organic byproducts. According to fragmentation rules of organic species under electron ionization conditions, the byproducts were identified by comparing mass spectra with National Institute of Standards and Technology (NIST) mass spectral library data.

\section{Results and discussion}

\subsection{Degradation of DDC by the $\mathrm{O}_{3}, \mathrm{UV}_{254 \mathrm{~nm}}, \mathrm{VUV}, \mathrm{O}_{3} /$ $\mathrm{UV}_{254 \mathrm{~nm}}$ and $\mathrm{O}_{3} / \mathrm{VUV}$}

The degradation performances of DDC by the $\mathrm{O}_{3}, \mathrm{UV}_{254 \mathrm{~nm}}$, VUV, $\mathrm{O}_{3} / \mathrm{UV}_{254 \mathrm{~nm}}$ and $\mathrm{O}_{3} / \mathrm{VUV}$ processes were compared, and the results are shown in Fig. 2 and listed in Table 1. The $\mathrm{O}_{3}$ dosage rate was $1.16 \mathrm{mg} \mathrm{min}{ }^{-1} \mathrm{~L}^{-1}$ and initial $\mathrm{pH}$ of DDC solution was 10.0. In this work, the removal of DDC by $\mathrm{O}_{3}$, 


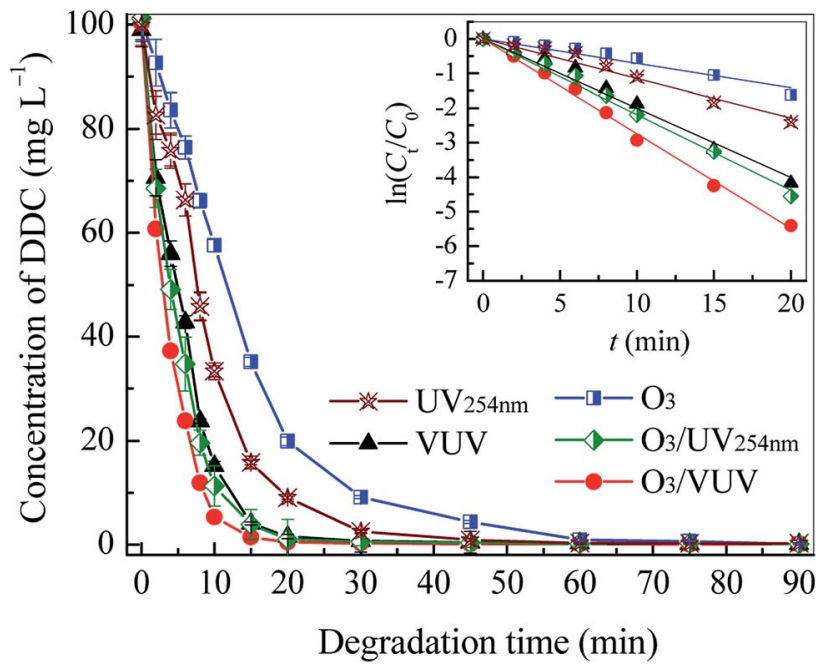

Fig. 2 The variations of DDC concentration with degradation time in the $\mathrm{O}_{3}, \cup V_{254 \mathrm{~nm}}, V U V, \mathrm{O}_{3} / \mathrm{UV}_{254 \mathrm{~nm}}$ and $\mathrm{O}_{3} / \mathrm{VUV}$ process. The inset figure was the pseudo-first-order kinetic fitting of $\ln \left(C / C_{0}\right)$ versus time t.

$\mathrm{UV}_{254 \mathrm{~nm}}, \mathrm{VUV}, \mathrm{O}_{3} / \mathrm{UV}_{254 \mathrm{~nm}}$ and $\mathrm{O}_{3} / \mathrm{VUV}$ could be described with a pseudo-first order kinetic equation (eqn (6)),

$$
\ln \left(C / C_{0}\right)=-k_{\text {app }} t
$$

where, $C$ and $C_{0}\left(\mathrm{mg} \mathrm{L}^{-1}\right)$ were the DDC concentration at degradation time $t$ and initial, respectively, $k_{\text {app }}\left(\mathrm{min}^{-1}\right)$ was the pseudo-first order rate constant, and $t$ (min) was degradation time.

As shown in Fig. 2 and Table 1, the $\mathrm{UV}_{254 \mathrm{~nm}}$ photolysis had achieved the higher DDC removal and larger degradation rate constant $\left(k_{\text {app }}\right)$ than $\mathrm{O}_{3}$-alone. It seemed that the DDC could be readily degraded by absorbing UV radiation. As indicated in our previous work, the DDC had a maximum UV absorption at $256 \mathrm{~nm} .{ }^{20}$ Thus, the degradation may be initiated by exciting DDC molecules with the absorption of $\mathrm{UV}_{254 \mathrm{~nm}}$ light. As given in Table 1, the $k_{\text {app }}$ obtained by VUV photolysis was 1.75 times higher than that by $\mathrm{UV}_{254 \mathrm{~nm}}$ photolysis, revealing that $\mathrm{OH}$ radicals generated by $185 \mathrm{~nm}$ VUV irradiation of $\mathrm{H}_{2} \mathrm{O}$ (eqn (1) and (2)) had promoted the DDC degradation. ${ }^{31}$ However, it should be noted that the degradation initiated by direct absorption of UV radiation ( $\mathrm{UV}_{254 \mathrm{~nm}}$ and $185 \mathrm{~nm}$ VUV)

Table 1 The removal efficiency at $20 \mathrm{~min}$, degradation rate constant $\left(k_{\text {app }}\right)$, half-life $\left(t_{1 / 2}\right)$ and correlation coefficient $\left(R^{2}\right)$ in the degradation of DDC by the $\mathrm{O}_{3}, U_{254 \mathrm{~nm}}, \mathrm{VUV}, \mathrm{O}_{3} / \mathrm{UV}_{254 \mathrm{~nm}}$ and $\mathrm{O}_{3} / \mathrm{VUV}$, respectively

\begin{tabular}{lllll}
\hline Process & $\begin{array}{l}\text { Removal efficiency } \\
\text { at } 20 \mathrm{~min}(\%)\end{array}$ & $k_{\text {app }}\left(\mathrm{min}^{-1}\right)$ & $t_{1 / 2}(\mathrm{~min})$ & $R^{2}$ \\
\hline $\mathrm{O}_{3}$ & 80.25 & 0.0687 & 10.09 & 0.992 \\
$\mathrm{UV}_{254 \mathrm{~nm}}$ & 90.96 & 0.115 & 6.03 & 0.984 \\
$\mathrm{VUV}$ & 98.45 & 0.201 & 3.45 & 0.991 \\
$\mathrm{O}_{3} / \mathrm{UV}_{254 \mathrm{~nm}}$ & 98.94 & 0.219 & 3.17 & 0.996 \\
$\mathrm{O}_{3} / \mathrm{VUV}$ & 99.55 & 0.274 & 2.53 & 0.998
\end{tabular}

was still the main mechanism for the DDC removal in the VUV photolysis.

The $k_{\text {app }}$ achieved by the $\mathrm{O}_{3} / \mathrm{UV}_{254 \mathrm{~nm}}$ was $0.219 \mathrm{~min}^{-1}$, much higher than that by $\mathrm{UV}_{254 \mathrm{~nm}}$ photolysis and $\mathrm{O}_{3}$-alone, respectively. As mentioned above, the $\mathrm{UV}_{254 \mathrm{~nm}}$ photolysis of dissolved $\mathrm{O}_{3}$ can yield $\mathrm{H}_{2} \mathrm{O}_{2}$, which in turn reacts with $\mathrm{O}_{3}$ or $\mathrm{UV}_{254 \mathrm{~nm}}$ radiation to generate ${ }^{\circ} \mathrm{OH}$ radicals as specified in eqn (3)-(5). ${ }^{32}$ The formation of ' $\mathrm{OH}$ radicals plays a key role in DDC degradation by the $\mathrm{O}_{3} / \mathrm{UV}_{254 \mathrm{~nm}}$. In this case, the $\mathrm{O}_{3} / \mathrm{UV}_{254 \mathrm{~nm}}$ could be also formed in the $\mathrm{O}_{3} / \mathrm{VUV}$ system by combining dosed $\mathrm{O}_{3}$ and $\mathrm{UV}_{254 \mathrm{~nm}}$ radiation emitted from the VUV lamp. As given in Table 1 , the $\mathrm{O}_{3} / \mathrm{UV}_{254 \mathrm{~nm}}$ and VUV photolysis had achieved much higher $k_{\text {app }}$ value compared to $\mathrm{O}_{3}$-alone, revealing that two former processes were main mechanisms for the DDC removal in the $\mathrm{O}_{3} /$ VUV system.

For all processes tested, the $\mathrm{O}_{3} / \mathrm{VUV}$ could achieve the highest degradation rate of DDC. Specially, the $k_{\text {app }}$ obtained by the $\mathrm{O}_{3} / \mathrm{VUV}$ was 3.99 times higher than that by $\mathrm{O}_{3}$-alone. Since the $U V_{254 \mathrm{~nm}}$ and VUV lamps used in this work had same electric power, the $\mathrm{O}_{3} / \mathrm{VUV}$ and $\mathrm{O}_{3} / \mathrm{UV}_{254 \mathrm{~nm}}$ had same energy consumption in DDC removal. However, it can be seen that the $\mathrm{O}_{3} / \mathrm{VUV}$ had the higher DDC degradation rate as given in Table 1 . Consequently, it was quite evident that the $\mathrm{O}_{3} / \mathrm{VUV}$ was more suitable for the DDC removal compared to the $\mathrm{O}_{3} /$ $\mathrm{UV}_{254 \mathrm{~nm}}$. In the previous biodegradation of DDC, the degradation rate constant of 0.45 day $^{-1}\left(3.125 \times 10^{-4} \mathrm{~min}^{-1}\right)$ was reported, suggesting that the removal of DDC by the biodegradation was extremely low. ${ }^{18}$ Although the DDC was found to be effectively oxidized by hypochlorite, the high dosage of hypochlorite, for example $400 \mathrm{~g} \mathrm{~L}^{-1}$, might result in potential secondary pollution of free chlorite and high process cost. ${ }^{21}$ Based on above results, it was considered that the $\mathrm{O}_{3} / \mathrm{VUV}$ could be used to remove high concentration DDC collector from flotation wastewaters with fast reaction kinetics.

\subsection{Effect of $\mathrm{O}_{3}$ dosage}

The $\mathrm{O}_{3}$ dosage is one of key parameters for $\mathrm{O}_{3}$-based AOPs. It determines both the removal efficiency of pollutants and the treatment cost. In this work, the $\mathrm{O}_{3}$ dosage rate was chosen to be as low as $0.62-1.27 \mathrm{mg} \mathrm{min}{ }^{-1} \mathrm{~L}^{-1}$ to investigate the removal of DDC by the $\mathrm{O}_{3} /$ VUV. As shown in Fig. 3, when the $\mathrm{O}_{3}$ dosage rate increased from 0.62 to $1.27 \mathrm{mg} \mathrm{min}^{-1} \mathrm{~L}^{-1}$, the $k_{\text {app }}$ for the $\mathrm{O}_{3}$ and $\mathrm{O}_{3} / \mathrm{VUV}$ rose from 0.0199 to $0.0826 \mathrm{~min}^{-1}$ and from 0.211 to $0.308 \mathrm{~min}^{-1}$, respectively. These results indicate that the DDC degradation could be significantly enhanced at higher $\mathrm{O}_{3}$ dosage. It can be attributed to the higher yield of ${ }^{\circ} \mathrm{OH}$ radicals by combining $\mathrm{O}_{3}$ and $\mathrm{UV}_{254 \mathrm{~nm}}$ radiation together. However, as shown in Fig. 3, the $k_{\text {app }}$ obtained by VUV photolysis had reached $0.201 \mathrm{~min}^{-1}$, much higher than that $\left(0.0826 \mathrm{~min}^{-1}\right)$ by $\mathrm{O}_{3}$-alone even at the highest $\mathrm{O}_{3}$ dosage rate of $1.27 \mathrm{mg} \mathrm{min}{ }^{-1} \mathrm{~L}^{-1}$. As discussed above, the $\mathrm{O}_{3} / \mathrm{UV}_{254 \mathrm{~nm}}$ and VUV photolysis were two main mechanisms for DDC removal in the $\mathrm{O}_{3} / \mathrm{VUV}$ system. Thus, the $\mathrm{O}_{3} / \mathrm{VUV}$ in this case can achieve high efficiency of DDC removal even at low $\mathrm{O}_{3}$ dosage. 


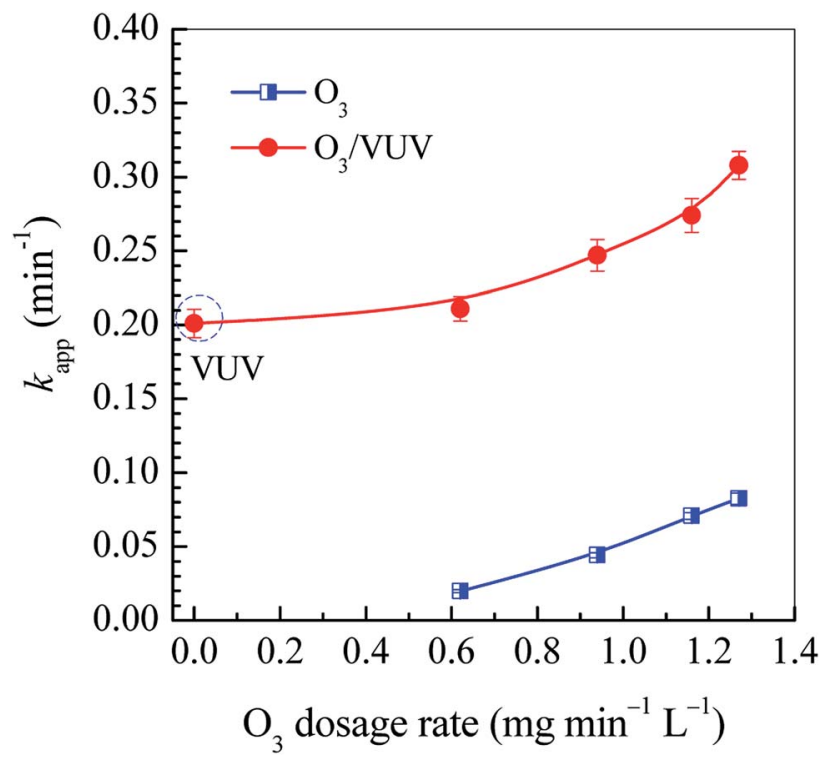

Fig. 3 The rate constants $\left(k_{\text {app }}\right)$ in the $\mathrm{O}_{3}$ and $\mathrm{O}_{3} / \mathrm{VUV}$ degradation of DDC.

\subsection{Mineralization of $\mathrm{C}, \mathrm{S}$ and $\mathrm{N}$ elements of DDC}

As shown in Fig. $\mathrm{S} 1$ (see in the ESI $\dagger$ ), the DDC molecule contains functional $\mathrm{S}$ and $\mathrm{N}$ atoms. Thus, inorganic anions such as $\mathrm{SO}_{4}{ }^{2-}$ and $\mathrm{NO}_{3}{ }^{-}$may be generated in the degradation of DDC. ${ }^{20}$ As shown in Fig. 4, the ion chromatographic analysis exhibited that both sulfate $\left(\mathrm{SO}_{4}{ }^{2-}\right)$ and nitrate $\left(\mathrm{NO}_{3}{ }^{-}\right)$anions were generated after the oxidation of DDC by the $\mathrm{O}_{3}$ and $\mathrm{O}_{3} / \mathrm{VUV}$, respectively. Other ionic species such as $\mathrm{SO}_{3}{ }^{2-}, \mathrm{S}_{2} \mathrm{O}_{3}{ }^{2-}$ and $\mathrm{NO}_{2}{ }^{-}$were not detected, suggesting that these species with low valences of $\mathrm{S}$ and $\mathrm{N}$ were further oxidized into $\mathrm{SO}_{4}{ }^{2-}$ and $\mathrm{NO}_{3}{ }^{-}$anions. ${ }^{33,34}$ It well demonstrated that the complete mineralization of DDC was feasible for both the $\mathrm{O}_{3}$ and $\mathrm{O}_{3} /$ VUV process. However, as shown in Fig. 4, the $\mathrm{O}_{3} / \mathrm{VUV}$ obtained higher peak intensity of either

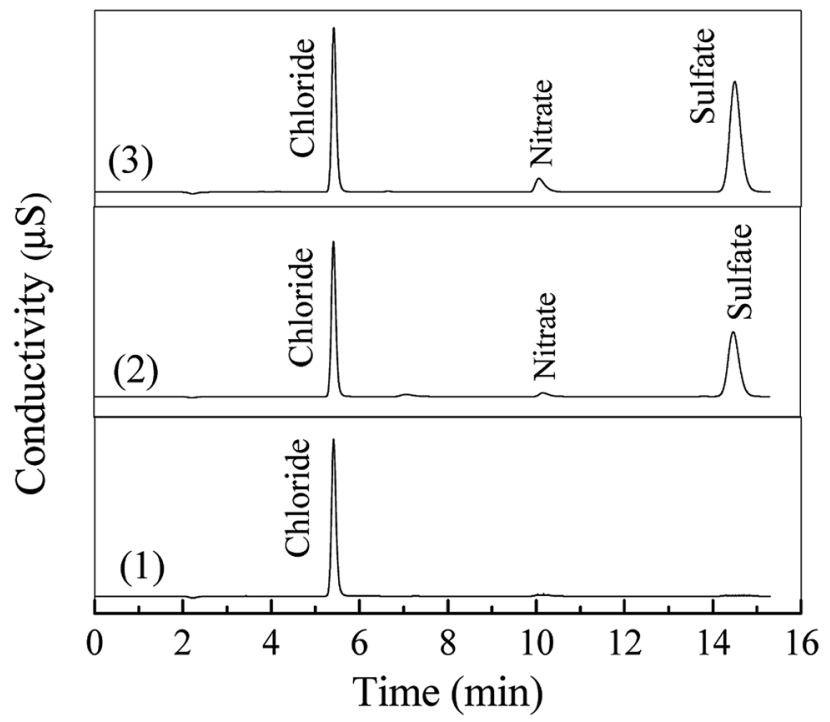

Fig. 4 Ion chromatographic analysis of $100 \mathrm{mg} \mathrm{L}^{-1}$ DDC solution treated at $0 \mathrm{~min}$ (1), $90 \mathrm{~min}$ by the $\mathrm{O}_{3}$ (2) and $\mathrm{O}_{3} / \mathrm{VUV}$ process (3).
$\mathrm{SO}_{4}{ }^{2-}$ or $\mathrm{NO}_{3}{ }^{-}$anion than $\mathrm{O}_{3}$-alone, indicating more $\mathrm{SO}_{4}{ }^{2-}$ and $\mathrm{NO}_{3}{ }^{-}$anions were accumulated in the $\mathrm{O}_{3} / \mathrm{VUV}$ system.

Fig. 5 showed the relative concentrations of DDC and TOC, and the changes of $\mathrm{SO}_{4}{ }^{2-}$ and $\mathrm{NO}_{3}{ }^{-}$concentrations. The concentrations of TOC, $\mathrm{SO}_{4}{ }^{2-}$ and $\mathrm{NO}_{3}{ }^{-}$at $90 \mathrm{~min}$ were also presented in Table 2. As shown in Fig. 5, with the rapid decrease of the $C / C_{0}$ of $\mathrm{DDC}$, the $\mathrm{TOC} / \mathrm{TOC}_{0}$ was also reduced with the increase of $\mathrm{SO}_{4}{ }^{2-}$ and $\mathrm{NO}_{3}{ }^{-}$concentrations, revealing the $\mathrm{C}, \mathrm{S}$ and $\mathrm{N}$ elements of DDC could be mineralized by the $\mathrm{O}_{3}$, VUV and $\mathrm{O}_{3} / \mathrm{VUV}$, respectively. However, as given in Table 2, the $\mathrm{O}_{3} /$ VUV obtained higher concentrations of $\mathrm{SO}_{4}{ }^{2-}$ and $\mathrm{NO}_{3}{ }^{-}$anions with lower TOC at 90 min than $\mathrm{O}_{3}$-alone and VUV photolysis.

In this work, to quantitatively describe the mineralization of DDC, the mineralization extents of $\mathrm{C}, \mathrm{S}$ and $\mathrm{N}$ elements were calculated. The mineralization extent of $\mathrm{C}$ was expressed by eqn $(7),{ }^{20}$

$$
\gamma_{\mathrm{C}}=\frac{\mathrm{TOC}_{0}-\mathrm{TOC}}{\mathrm{TOC}_{0}} \times 100 \%
$$

where, $\gamma_{\mathrm{C}}$ was the mineralization extent of $\mathrm{C}, \mathrm{TOC}_{0}$ and TOC were the TOC of DDC solution at initial and $90 \mathrm{~min}$, respectively. The mineralization extent of $\mathrm{S}$ or $\mathrm{N}$ element was defined by eqn (8):

$$
\gamma=\frac{171}{n \times M_{\text {anion }}} \times \frac{C_{\text {anion }}}{C_{0}} \times 100 \%
$$

where, $\gamma$ was the mineralization extent of $S\left(\gamma_{S}\right)$ or $N\left(\gamma_{N}\right)$ element of DDC, $n$ was the number of $\mathrm{S}$ or $\mathrm{N}$ atom of DDC, $M_{\text {anion }}$ was the relative molecular weight of $\mathrm{SO}_{4}{ }^{2-}$ or $\mathrm{NO}_{3}{ }^{-}$ anion, $C_{\text {anion }}\left(\mathrm{mg} \mathrm{L}^{-1}\right)$ was the concentration of $\mathrm{SO}_{4}{ }^{2-}$ or $\mathrm{NO}_{3}{ }^{-}$ at $90 \mathrm{~min}$, and $C_{0}\left(\mathrm{mg} \mathrm{L}^{-1}\right)$ was initial concentration of DDC. The mineralization extents of $\mathrm{C}, \mathrm{S}$ and $\mathrm{N}$ elements were summarized in Table 2. It can be found that the $\gamma_{\mathrm{C}}, \gamma_{\mathrm{S}}$ and $\gamma_{\mathrm{N}}$ at 90 min obtained by the $\mathrm{O}_{3} / \mathrm{VUV}$ were $1.72,3.71$ and 4.24 times higher than that by $\mathrm{O}_{3}$-alone, respectively. The higher extents of mineralization well revealed that both DDC and its byproducts were removed by the $\mathrm{O}_{3} / \mathrm{VUV}$ with higher degradation rates compared to $\mathrm{O}_{3}$-alone. However, in this work, the VUV photolysis achieved the higher mineralization extents of $\mathrm{C}, \mathrm{S}$ and $\mathrm{N}$ elements of DDC than $\mathrm{O}_{3}$-alone at the $\mathrm{O}_{3}$ dosage rate of 1.16 $\mathrm{mg} \min ^{-1} \mathrm{~L}^{-1}$, revealing that the VUV photolysis had made great contribution in further degradation of various byproducts for the $\mathrm{O}_{3} / \mathrm{VUV}$ process. As mentioned above, the $\mathrm{O}_{3} / \mathrm{UV}_{254 \mathrm{~nm}}$, VUV photolysis and the ozonation could be responsible for the generation of ${ }^{\circ} \mathrm{OH}$ radicals in the $\mathrm{O}_{3} /$ VUV system. Thus the $\mathrm{O}_{3} /$ VUV could obtain higher yields of oxidative species than $\mathrm{O}_{3}$ alone at same $\mathrm{O}_{3}$ dosage. As listed in Table 2, the mineralization extent of $\mathrm{C}, \mathrm{S}$ and $\mathrm{N}$ elements by the $\mathrm{O}_{3} / \mathrm{VUV}$ increased as following: $\gamma_{\mathrm{C}}<\gamma_{\mathrm{S}}<\gamma_{\mathrm{N}}$. The results suggested that the $\mathrm{S}$ and $\mathrm{N}$ elements of DDC were relatively easier to be mineralized compared to $\mathrm{C}$ element. Accordingly, it can be reasonably inferred that some organic byproducts without the $\mathrm{S}$ or $\mathrm{N}$ element might be accumulated in treated DDC solution.

\subsection{Generation of $\mathrm{CS}_{2}$ and $\mathrm{H}_{2} \mathrm{~S}$ byproducts}

It has been well documented that sulfur byproducts, such as carbon disulfide $\left(\mathrm{CS}_{2}\right)$, carbonyl sulfide (COS), hydrogen sulfide 

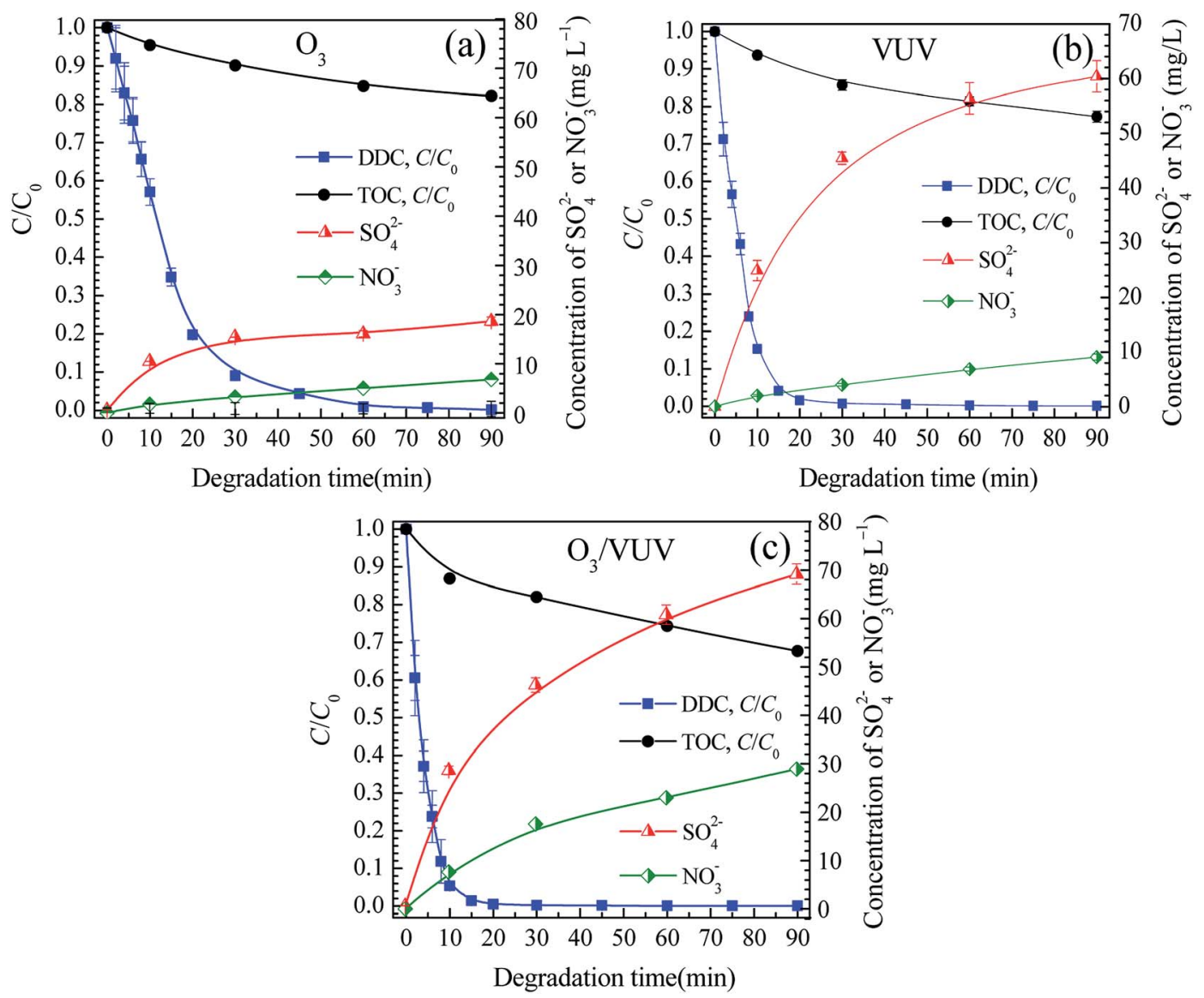

Fig. 5 The relative concentrations of DDC and TOC, and changes of $\mathrm{SO}_{4}{ }^{2-}$ and $\mathrm{NO}_{3}{ }^{-}$concentrations in the $\mathrm{O}_{3}$ (a), $\mathrm{VUV}$ (b) and $\mathrm{O}_{3} / \mathrm{VUV}$ (c) degradation of DDC.

$\left(\mathrm{H}_{2} \mathrm{~S}\right)$, sulfite $\left(\mathrm{SO}_{3}{ }^{2-}\right)$ and thiosulfate $\left(\mathrm{S}_{2} \mathrm{O}_{3}{ }^{2-}\right)$, are generated during the degradation of xanthate collectors by the AOPs. ${ }^{26,33,35,36}$ In this case, the DDC collector had same functional $-\mathrm{CSS}^{-}$group as the xanthates. Thus, above-mentioned sulfur byproducts might be also generated while the DDC was degraded. However, to the best of our knowledge, there is no report on the formation of sulfur byproducts during the DDC degradation by the AOPs. Because the $\mathrm{CS}_{2}$ and $\mathrm{H}_{2} \mathrm{~S}$ are typical toxic sulfur contaminants, the concentrations of aqueous $\mathrm{CS}_{2}$ and $\mathrm{H}_{2} \mathrm{~S}$ were determined while the DDC was degraded by the $\mathrm{O}_{3}$ and $\mathrm{O}_{3} / \mathrm{VUV}$, respectively. ${ }^{37,38}$ Since both the $\mathrm{CS}_{2}$ and $\mathrm{H}_{2} \mathrm{~S}$ are highly volatile, the amounts of gaseous $\mathrm{CS}_{2}$ and $\mathrm{H}_{2} \mathrm{~S}$ emitted into air were also measured to investigate the emission behaviors of $\mathrm{CS}_{2}$ and $\mathrm{H}_{2} \mathrm{~S}$ from treated DDC solutions.

Table 2 The concentrations of $\mathrm{TOC}_{1} \mathrm{SO}_{4}{ }^{2-}$, and $\mathrm{NO}_{3}{ }^{-}$anions at 90 min and the mineralization extents of $\mathrm{C}, \mathrm{S}$ and $\mathrm{N}$ elements of DDC by the $\mathrm{O}_{3}, \mathrm{VUV}$ and $\mathrm{O}_{3} / \mathrm{VUV}$, respectively

\begin{tabular}{llllllll}
\hline & \multicolumn{2}{l}{ Concentration $\left(\mathrm{mg} \mathrm{L}^{-1}\right)$} & & \multicolumn{4}{c}{ Mineralization extent (\%) } \\
\cline { 2 - 3 } Process & TOC & $\mathrm{SO}_{4}{ }^{2-}$ & $\mathrm{NO}_{3}{ }^{-}$ & & $\mathrm{C}$ & $\mathrm{S}$ & $\mathrm{N}$ \\
\hline $\mathrm{O}_{3}$ & 54.91 & 18.66 & 6.82 & & 18.85 & 16.91 & 18.81 \\
$\mathrm{VUV}$ & 51.67 & 60.42 & 9.07 & & 24.45 & 57.69 & 25.02 \\
$\mathrm{O}_{3} /$ VUV & 45.21 & 69.18 & 28.92 & & 32.36 & 62.69 & 79.76
\end{tabular}

Fig. 6 showed the concentrations of aqueous $\mathrm{CS}_{2}$ and $\mathrm{H}_{2} \mathrm{~S}$ in the $\mathrm{O}_{3}$ and $\mathrm{O}_{3} / \mathrm{VUV}$ degradation of DDC, respectively. During the degradation of DDC, the $\mathrm{CS}_{2}$ concentration increased up to a maximum value, and then decreased at longer time for both the $\mathrm{O}_{3}$ and $\mathrm{O}_{3} / \mathrm{VUV}$ process. At the initial stage, more $\mathrm{CS}_{2}$ was generated by the $\mathrm{O}_{3} /$ VUV compared to $\mathrm{O}_{3}$-alone. However, at $90 \mathrm{~min}$, the $\mathrm{CS}_{2}$ concentration was reduced to an extremely low level of $0.10 \mathrm{mg} \mathrm{L}^{-1}$ for the $\mathrm{O}_{3} / \mathrm{VUV}$, but was still as high as $0.89 \mathrm{mg} \mathrm{L}^{-1}$ for $\mathrm{O}_{3}$-alone. In general, aqueous $\mathrm{H}_{2} \mathrm{~S}$ concentrations had similar change behaviors to $\mathrm{CS}_{2}$ as shown in Fig. 6(b). Specially, when the $\mathrm{H}_{2} \mathrm{~S}$ concentration by the $\mathrm{O}_{3} / \mathrm{VUV}$ was decreased after $20 \mathrm{~min}$, it still increased significantly by $\mathrm{O}_{3}$ alone. Therefore, a low $\mathrm{H}_{2} \mathrm{~S}$ concentration of $0.16 \mathrm{mg} \mathrm{L}^{-1}$ for the $\mathrm{O}_{3}$ /VUV was obtained, but the $\mathrm{H}_{2} \mathrm{~S}$ concentration was as high as $3.34 \mathrm{mg} \mathrm{\textrm {L } ^ { - 1 }}$ for $\mathrm{O}_{3}$-alone after $90 \mathrm{~min}$ of DDC degradation. Consequently, although sulfur byproducts could be further oxidized by the $\mathrm{O}_{3}$ and $\mathrm{O}_{3} / \mathrm{VUV}$, the $\mathrm{O}_{3} / \mathrm{VUV}$ achieved much lower residual concentrations of $\mathrm{CS}_{2}$ and $\mathrm{H}_{2} \mathrm{~S}$, attributing to the enhanced yields of ${ }^{\circ} \mathrm{OH}$ radicals in the $\mathrm{O}_{3} / \mathrm{VUV}$ system.

Fig. 7 depicts the amounts of gaseous $\mathrm{CS}_{2}$ and $\mathrm{H}_{2} \mathrm{~S}$ emitted into air. The amount of emitted $\mathrm{CS}_{2}$ for the $\mathrm{O}_{3} / \mathrm{VUV}$ was slightly higher than that for $\mathrm{O}_{3}$-alone. As the $\mathrm{CS}_{2}$ was a volatile contaminant, the higher concentration of aqueous $\mathrm{CS}_{2}$ at initial stage (Fig. 6(a)) would release more $\mathrm{CS}_{2}$ into gas phase in the $\mathrm{O}_{3} /$ VUV system. As shown in Fig. 7, the amount of emitted $\mathrm{H}_{2} \mathrm{~S}$ for 

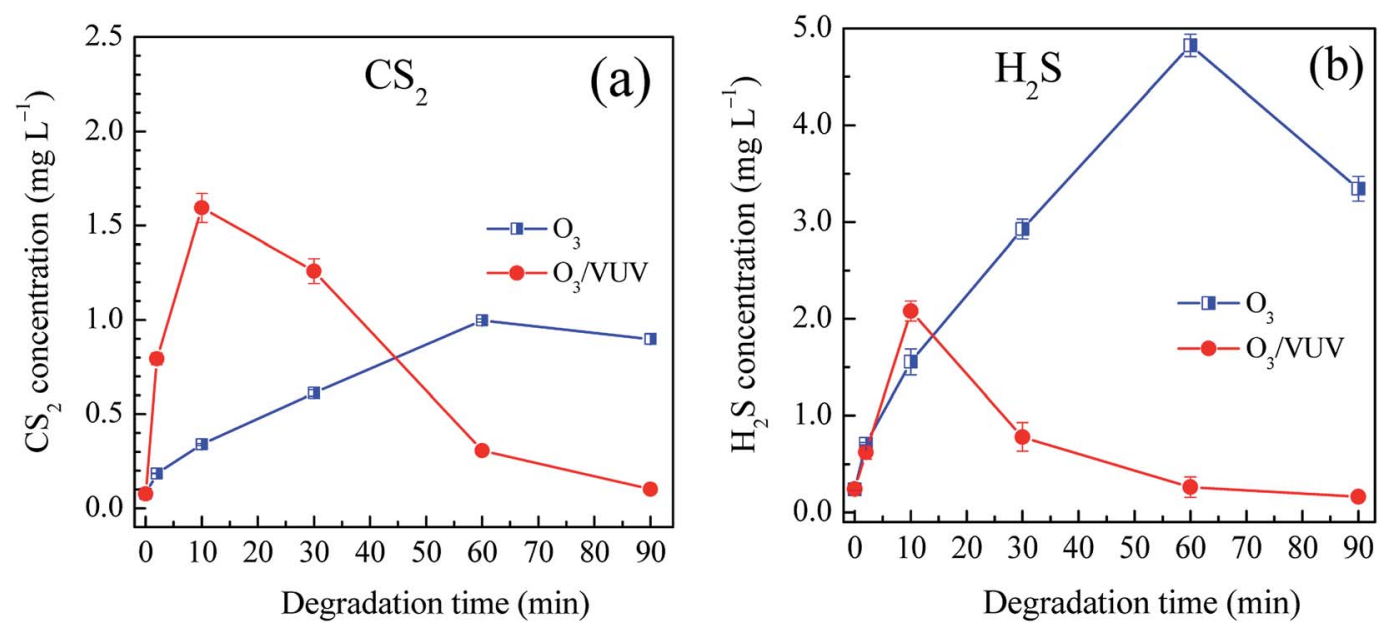

Fig. 6 The concentrations of aqueous $\mathrm{CS}_{2}(\mathrm{a})$ and $\mathrm{H}_{2} \mathrm{~S}(\mathrm{~b})$ byproducts in the $\mathrm{O}_{3}$ and $\mathrm{O}_{3} / \mathrm{VUV}$ degradation of DDC, respectively.

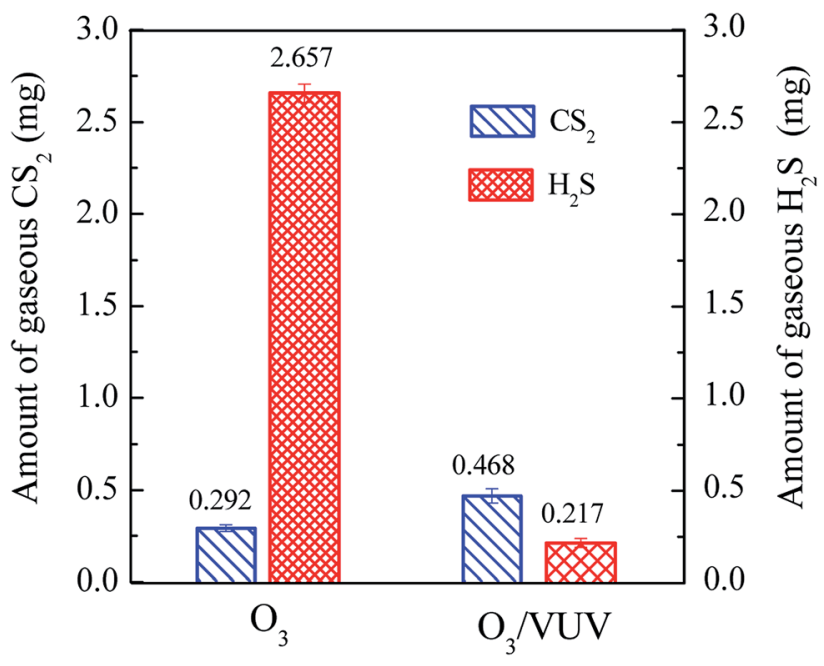

Fig. 7 The amounts of gaseous $\mathrm{CS}_{2}$ and $\mathrm{H}_{2} \mathrm{~S}$ emitted into air for $90 \mathrm{~min}$ in the $\mathrm{O}_{3}$ and $\mathrm{O}_{3}$ /VUV degradation of DDC

$\mathrm{O}_{3}$-alone was 12.24 times higher than that for the $\mathrm{O}_{3} / \mathrm{VUV}$. The results were well in accordance with much higher concentration of aqueous $\mathrm{H}_{2} \mathrm{~S}$ for $\mathrm{O}_{3}$-alone as indicated in Fig. 6(b). By considering the emission of $\mathrm{CS}_{2}$ and $\mathrm{H}_{2} \mathrm{~S}$ together, the amount of emitted $\mathrm{CS}_{2}$ and $\mathrm{H}_{2} \mathrm{~S}$ for the $\mathrm{O}_{3} / \mathrm{VUV}$ was just $0.685 \mathrm{mg}$, much lower than that $(2.949 \mathrm{mg})$ for $\mathrm{O}_{3}$-alone. In summary, in comparison with $\mathrm{O}_{3}$-alone, the $\mathrm{O}_{3} / \mathrm{VUV}$ achieved lower aqueous concentrations and less emitted amounts of sulfur byproducts $\left(\mathrm{CS}_{2}\right.$ and $\left.\mathrm{H}_{2} \mathrm{~S}\right)$ during the degradation of DDC. The result revealed that the release of toxic $\mathrm{CS}_{2}$ and $\mathrm{H}_{2} \mathrm{~S}$ could be inhibited by the $\mathrm{O}_{3} / \mathrm{VUV}$ degradation of DDC.

\subsection{Byproducts identified by SPE/GC-MS}

To better understand the degradation mechanism of DDC, the SPE/GC-MS analysis was employed to identify organic byproducts generated in the $\mathrm{O}_{3} / \mathrm{VUV}$ degradation of DDC. All the peaks with a response on mass spectrometry were marked in Fig. 8. Identified byproducts were summarized in Tables 3 and 4 with retention time and other special characteristics. The mass spectrums of identified byproducts were shown in Fig. S3 (see in the ESI†).

As shown in Fig. 8 and Table 3, six amide byproducts were detected at $20 \mathrm{~min}$, and the $N, N$-diethylformamide (peak 1) was the main byproduct of DDC degradation. Since the removal of DDC at 20 min had reached $99.85 \%$ as given in Table 1, the DDC was not detected. By extending the degradation time from 20 to $90 \mathrm{~min}$, the relative abundance of $N, N$-diethylformamide (peak 1) was remarkably decreased. Meanwhile, the peaks of $N, N$ dimethylacetamide (peak 2), $\mathrm{N}$-ethylacetamide (peak 3) and $\mathrm{N}$ methylacetamide (peak 4) disappeared completely. The results indicated the further decomposition of these amines by the $\mathrm{O}_{3} /$ VUV. Nevertheless, the relative abundance of 5,6-dihydro thymine (peak 5) and $N$-formyl- $N$-methylformamide (peak 6) increased, and the diacetamide (peak 7) appeared as shown in Fig. 8. Because almost $100 \%$ removal of DDC was achieved after

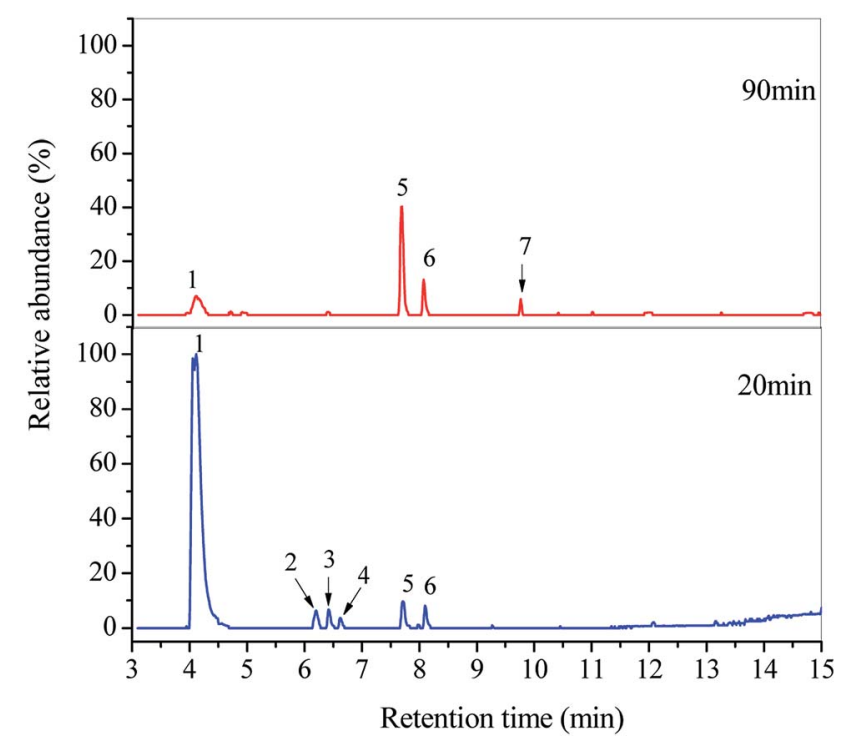

Fig. 8 GC-MS total ion chromatograms of DDC solutions treated at 20 and 90 min in the $\mathrm{O}_{3} /$ VUV degradation of DDC. 
Table 3 GC-MS retention time and special characteristics of identified byproducts in the $\mathrm{O}_{3} / \mathrm{VUV}$ degradation of DDC at 20 min

\begin{tabular}{|c|c|c|c|c|c|}
\hline No. & $\begin{array}{l}\text { Molecular } \\
\text { formula }\end{array}$ & Compounds & Retention time (min) & Similarity (\%) & Main characteristic ions $(\mathrm{m} / \mathrm{z})$ \\
\hline 1 & $\mathrm{C}_{5} \mathrm{H}_{11} \mathrm{NO}$ & $N, N$-diethylformamide & 4.099 & 99 & $58,72,86,101,102$ \\
\hline 3 & $\mathrm{C}_{4} \mathrm{H}_{9} \mathrm{NO}$ & $N$-ethylacetamide & 6.406 & 96 & 72,87 \\
\hline 4 & $\mathrm{C}_{3} \mathrm{H}_{7} \mathrm{NO}$ & $N$-methylacetamide & 6.607 & 97 & 58,73 \\
\hline 5 & $\mathrm{C}_{5} \mathrm{H}_{8} \mathrm{~N}_{2} \mathrm{O}_{2}$ & 5,6-Dihydro thymine & 7.697 & 99 & $127,128,129$ \\
\hline
\end{tabular}

$20 \mathrm{~min}$, these three amides should be generated from certain intermediates. Consequently, the number of organic byproducts of DDC could be reduced by extending the reaction time.

In this work, main byproducts in the $\mathrm{O}_{3}$ /VUV degradation of DDC were amide compounds without the generation of $\mathrm{N}$-nitrosamines such as NDEA. However, the formation of NDEA was previously observed in the oxidation of DDC with $\mathrm{Cl}_{2}, \mathrm{NaClO}_{2}$ and $\mathrm{O}_{3}$, respectively. ${ }^{11}$ In the $\mathrm{O}_{3} / \mathrm{VUV}$ degradation of $\mathrm{DDC}$, two mechanisms, i.e., UV photolysis and enhanced ${ }^{\circ} \mathrm{OH}$ radical formation, may contribute to the inhibition of $N$-nitrosamine formation. Because $\mathrm{N}$-nitrosamines have a strong UV absorption via the homolytic cleavage of the $\mathrm{N}-\mathrm{N}$ bond, the UV photolysis was proved to degrade $N$-nitrosamines effectively through $\mathrm{N}-\mathrm{N}$ bond fission. ${ }^{29,39}$ The rate constant for NDEA degradation under UV irradiation reached $2.60 \times 10^{-2}$ and $1.62 \times 10^{-3} \mathrm{mmol}$ $\mathrm{L}^{-1} \min ^{-1}$ at $\mathrm{pH} 6.0$ and 10.0 , respectively. ${ }^{39}$ In this $\mathrm{O}_{3} / \mathrm{VUV}$ system, the UV $\left(\mathrm{UV}_{254 \mathrm{~nm}}+185 \mathrm{~nm}\right.$ VUV$)$ photolysis may promote to the degradation of possibly generated $N$-nitrosamines.

Previous studies had concluded that an oxidation system with the higher yield of ${ }^{\circ} \mathrm{OH}$ radicals could achieve higher degradation rate of NDEA. ${ }^{23,24}$ For instances, compared to $\mathrm{O}_{3}$-alone, the $\mathrm{UV} / \mathrm{O}_{3}$ could inhibit the regeneration of NDEA effectively via the interaction of NDEA and ${ }^{\circ} \mathrm{OH}$ radicals. ${ }^{23,24}$ As mentioned above, the rate constant of NDEA degradation with ${ }^{\circ} \mathrm{OH}$ radicals is nearly 9 orders higher than that with the $\mathrm{O}_{3}{ }^{22}$ Therefore, ${ }^{\circ} \mathrm{OH}$ radicals are the key oxidant for NDEA degradation. In this case, three mechanisms, i.e., the ozonation, $\mathrm{VUV}$ photolysis and $\mathrm{O}_{3} / \mathrm{UV}_{254 \mathrm{~nm}}$, had made contributions to the formation of ${ }^{\circ} \mathrm{OH}$ radicals in the $\mathrm{O}_{3}$ /VUV system, resulting in much higher yield of ${ }^{\circ} \mathrm{OH}$ radicals compared to $\mathrm{O}_{3}$-alone. Therefore, the degradation of possible $\mathrm{N}$ nitrosamines would be enhanced, and the $N$-nitrosamine formation was inhibited by the $\mathrm{O}_{3}$ /VUV.

\subsection{Possible degradation pathways of DDC by the $\mathrm{O}_{3} / \mathrm{VUV}$}

In this work, the degradation pathways of DDC by the $\mathrm{O}_{3} / \mathrm{VUV}$ were proposed as shown in Fig. 9. The degradation of DDC may have three pathways. As shown in Fig. 8, the $N, N$-diethylformamide was the primary byproduct of DDC degradation. Therefore, the main pathway (pathway 1) may be the oxidation of the ${ }^{-\mathrm{CSS}^{-}}$group of DDC into - CHO group to form the $\mathrm{N}, \mathrm{N}$ diethylformamide. Simultaneously, the $\mathrm{S}^{2-}$ ions are released (eqn (9)). Another two pathways of DDC degradation may be related to the generation of the diethylamine (DEA). Although the DEA was not detected by SPE/GC-MS, the formation of DEA was previously reported through the hydrolysis or the oxidation of DDC. ${ }^{11}$ As mentioned above, the DDC can be easily hydrolyzed to DEA with the release of $\mathrm{CS}_{2}$ (eqn (10)). ${ }^{40}$ But the hydrolysis of DDC can be inhibited in alkaline $\mathrm{pH}$. For example, the hydrolysis rate constant of DDC at pH 5 is $9.2 \times 10^{-4} \mathrm{~s}^{-1}$, but the rate constant at $\mathrm{pH} 9$ is remarkably reduced to $1.0 \times$ $10^{-7} \mathrm{~s}^{-1} \cdot{ }^{11}$ In this work, initial $\mathrm{pH}$ of DDC solution was 10.0, meaning that the DEA formation from the hydrolysis of DDC (pathway 2) may be low efficient. Thus, the yield of DEA (pathway 3) should be mainly attributed to the breaking of $\mathrm{N}-\mathrm{C}$ bond of DDC by ${ }^{\circ} \mathrm{OH}$ radicals (eqn (11)).

$$
\begin{gathered}
\left(\mathrm{CH}_{3} \mathrm{CH}_{2}\right)_{2} \mathrm{NCSS}^{-}+{ }^{\cdot} \mathrm{OH} \rightarrow\left(\mathrm{CH}_{3} \mathrm{CH}_{2}\right)_{2} \mathrm{NCHO}+\mathrm{S}^{2-} \\
\text { Hydrolysis: }\left(\mathrm{CH}_{3} \mathrm{CH}_{2}\right)_{2} \mathrm{NCSS}^{-} \rightarrow\left(\mathrm{CH}_{3} \mathrm{CH}_{2}\right)_{2} \mathrm{NH}+\mathrm{CS}_{2} \\
\text { Oxidation: }\left(\mathrm{CH}_{3} \mathrm{CH}_{2}\right)_{2} \mathrm{NCSS}^{-}+{ }^{\cdot} \mathrm{OH} \rightarrow\left(\mathrm{CH}_{3} \mathrm{CH}_{2}\right)_{2} \mathrm{NH} \\
+\mathrm{CS}_{2}
\end{gathered}
$$

The DEA can be effectively oxidized by ${ }^{\circ} \mathrm{OH}$ radicals. ${ }^{\mathbf{4 1 , 4 2}}$ The $\mathrm{H}$-atom abstraction by ${ }^{\circ} \mathrm{OH}$ radicals from $-\mathrm{NH}$ and $\mathrm{CH}_{2}$ groups of DEA may occur (eqn (12) and (13)). ${ }^{41}$ The $N$-ethylacetamide may be generated from eqn (13) and (14). Then, the $N$-ethylacetamide can be further oxidized to diacetamide, $N$-methylacetamide and $N, N$-dimethylacetamide. As shown in Fig. 8, the relative abundance of 5,6-dihydro thymine and $N$-formyl- $N$ methyl formamide increased with the degradation of the $N, N$ diethyl formamide while the degradation time rose from 20 to

Table 4 GC-MS retention time and special characteristics of identified byproducts in the $\mathrm{O}_{3} / \mathrm{VUV}$ degradation of DDC at 90 min

\begin{tabular}{llllll}
\hline No. & $\begin{array}{l}\text { Molecular } \\
\text { formula }\end{array}$ & Compounds & Retention time (min) & Similarity (\%) & Main characteristic ions $(m / z)$ \\
\hline 1 & $\mathrm{C}_{5} \mathrm{H}_{11} \mathrm{NO}$ & $N, N$-diethylformamide & 4.101 & 96 & $57,58,86,101$ \\
5 & $\mathrm{C}_{5} \mathrm{H}_{8} \mathrm{~N}_{2} \mathrm{O}_{2}$ & 5,6 -Dihydro thymine & 7.692 & 95 & $102,127,128,129$ \\
6 & $\mathrm{C}_{3} \mathrm{H}_{5} \mathrm{NO}_{2}$ & $N$-formyl- $N$-methylformamide & 8.075 & 99 & 59,87 \\
7 & $\mathrm{C}_{4} \mathrm{H}_{7} \mathrm{NO}_{2}$ & Diacetamide & 9.767 & 94 & $59,60,73$
\end{tabular}




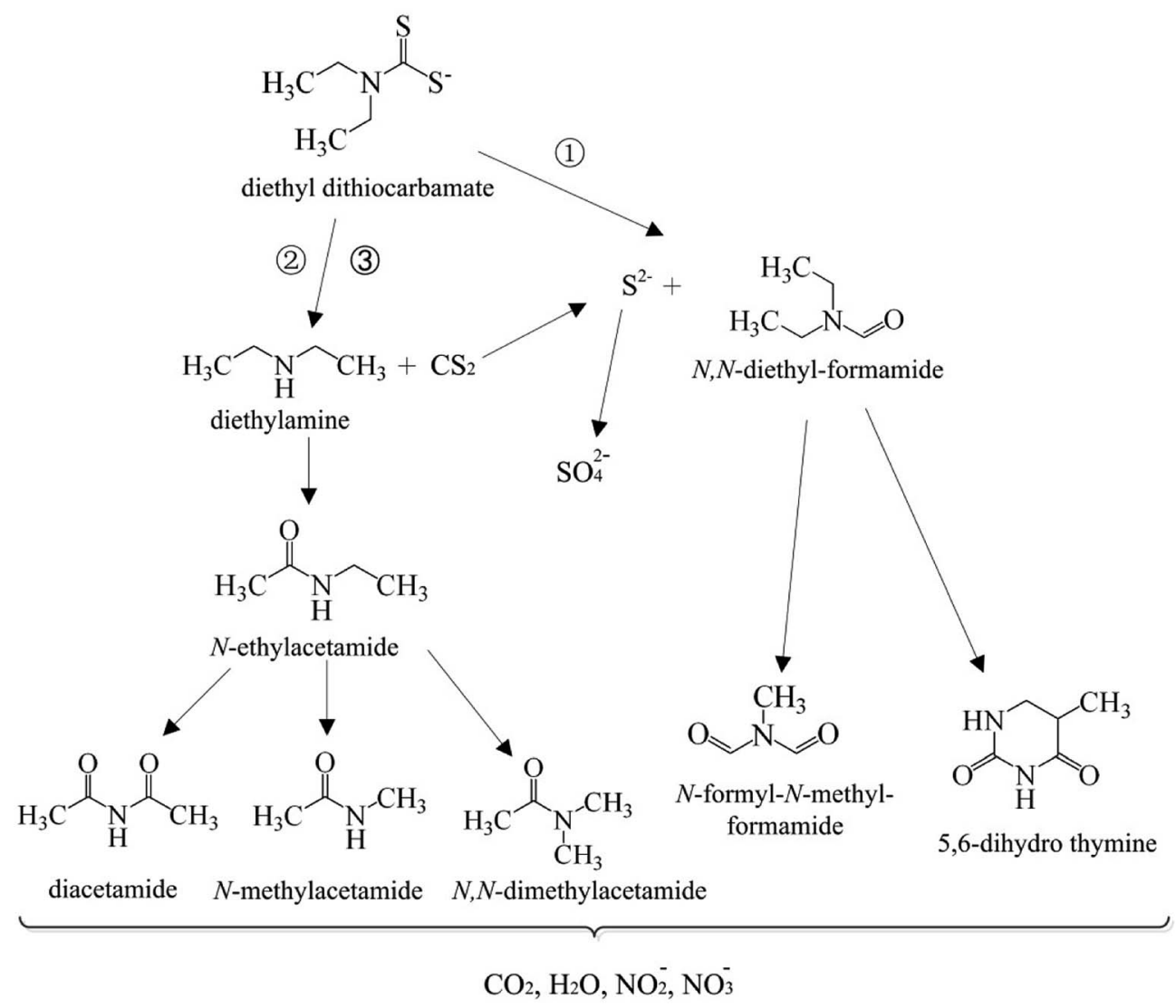

Fig. 9 Proposed degradation pathways of DDC by the $\mathrm{O}_{3} / \mathrm{VUV}$ process.

$90 \mathrm{~min}$. Therefore, the 5,6-dihydro thymine and $\mathrm{N}$-formyl- $\mathrm{N}$ methyl formamide may be generated from the degradation of $\mathrm{N}, \mathrm{N}$-diethylformamide. Finally, these amide compounds can be completely mineralized to $\mathrm{CO}_{2}, \mathrm{H}_{2} \mathrm{O}, \mathrm{NO}_{2}{ }^{-}$, and $\mathrm{NO}_{3}{ }^{-}$anions by $\cdot \mathrm{OH}$ radicals.

$$
\begin{gathered}
\left(\mathrm{CH}_{3} \mathrm{CH}_{2}\right)_{2} \mathrm{NH}+{ }^{\circ} \mathrm{OH} \rightarrow\left(\mathrm{CH}_{3} \mathrm{CH}_{2}\right)_{2} \mathrm{~N}^{\cdot}+\mathrm{H}_{2} \mathrm{O} \\
\left(\mathrm{CH}_{3} \mathrm{CH}_{2}\right)_{2} \mathrm{NH}+{ }^{\circ} \mathrm{OH} \rightarrow\left(\mathrm{CH}_{3} \mathrm{CH}_{2}\right) \mathrm{NHC}^{\cdot} \mathrm{HCH}_{3}+\mathrm{H}_{2} \mathrm{O} \\
\left(\mathrm{CH}_{3} \mathrm{CH}_{2}\right) \mathrm{NHC}^{\cdot} \mathrm{HCH}_{3}+{ }^{\circ} \mathrm{O} \rightarrow\left(\mathrm{CH}_{3} \mathrm{CH}_{2}\right) \mathrm{NHCHOCH}_{3}
\end{gathered}
$$

The $\mathrm{CS}_{2}$ byproduct generated via eqn (10) and (11) can react with ${ }^{\circ} \mathrm{OH}$ radicals to produce dithiocarbonate ions $\left({ }^{\circ} \mathrm{CS}_{2} \mathrm{OH}\right)$ (eqn (15))..$^{43}$ Subsequently, the ${ }^{\circ} \mathrm{CS}_{2} \mathrm{OH}$ is decomposed instantaneously to produce hydrogen sulfide radicals ('HS) and carbonyl sulfide (COS) (eqn (16)). ${ }^{44}$ The aqueous COS may be hydrolyzed to produce hydrogen sulfide $\left(\mathrm{H}_{2} \mathrm{~S}\right)($ eqn $(17)){ }^{45}$ Then, $\mathrm{S}^{2-}$ species generated from eqn (9) and (17) were further oxidized into $\mathrm{SO}_{4}{ }^{2-}$ anions (eqn (18)). ${ }^{46}$ The decreased concentrations of aqueous $\mathrm{CS}_{2}$ and $\mathrm{H}_{2} \mathrm{~S}$ well demonstrated the oxidation of $\mathrm{CS}_{2}$ and $\mathrm{H}_{2} \mathrm{~S}$ in the $\mathrm{O}_{3} / \mathrm{VUV}$ system.

$$
\begin{aligned}
& \mathrm{CS}_{2}+{ }^{\circ} \mathrm{OH} \rightarrow \mathrm{CS}_{2} \mathrm{OH}^{\cdot} \\
& \mathrm{CS}_{2} \mathrm{OH}^{\cdot} \rightarrow \mathrm{COS}+\mathrm{HS}^{\cdot}
\end{aligned}
$$

$$
\begin{aligned}
& \mathrm{COS}+\mathrm{H}_{2} \mathrm{O} \rightarrow \mathrm{H}_{2} \mathrm{~S}+\mathrm{CO}_{2} \\
& \mathrm{~S}^{2-}+{ }^{\cdot} \mathrm{OH} \rightarrow \mathrm{SO}_{4}{ }^{2-}+\mathrm{H}_{2} \mathrm{O}
\end{aligned}
$$

\section{Conclusions}

The degradation of DDC collector with initial concentration of $100 \mathrm{mg} \mathrm{L}^{-1}$ was performed by the $\mathrm{O}_{3}$ and $\mathrm{O}_{3} / \mathrm{VUV}$ process, respectively. Compared to $\mathrm{O}_{3}$-alone, the $\mathrm{O}_{3} / \mathrm{VUV}$ achieved higher removal efficiency and mineralization extents of DDC. The rate constant of DDC degradation by the $\mathrm{O}_{3} / \mathrm{VUV}$ was 3.99 times higher than that by $\mathrm{O}_{3}$-alone. For the $\mathrm{O}_{3} / \mathrm{VUV}$, the removal of DDC reached $99.55 \%$ at $20 \mathrm{~min}$, and the mineralization extents of $\mathrm{C}, \mathrm{S}$ and $\mathrm{N}$ elements reached $36.36 \%, 62.69 \%$ and $79.76 \%$ at $90 \mathrm{~min}$, respectively. In the $\mathrm{O}_{3} / \mathrm{VUV}$ system, the $\mathrm{O}_{3} / \mathrm{UV}_{254 \mathrm{~nm}}$ and VUV photolysis were two main mechanisms for DDC removal. At the end of degradation $(90 \mathrm{~min})$, the residual concentrations of aqueous $\mathrm{CS}_{2}$ and $\mathrm{H}_{2} \mathrm{~S}$ were reduced to 0.10 and $0.16 \mathrm{mg} \mathrm{L}^{-1}$ for the $\mathrm{O}_{3} / \mathrm{VUV}$, but were still as high as 0.89 and $3.34 \mathrm{mg} \mathrm{L}^{-1}$ for $\mathrm{O}_{3}$-alone, respectively. Simultaneously, the $\mathrm{O}_{3} / \mathrm{VUV}$ released lower amount of gaseous $\mathrm{CS}_{2}$ and $\mathrm{H}_{2} \mathrm{~S}$. The results indicated that the $\mathrm{O}_{3} / \mathrm{VUV}$ could inhibit the release of $\mathrm{CS}_{2}$ and $\mathrm{H}_{2} \mathrm{~S}$ byproducts in the degradation of DDC. 
Main byproducts in the $\mathrm{O}_{3} / \mathrm{VUV}$ degradation of DDC were amide compounds such as $\mathrm{N}, \mathrm{N}$-diethylformamide. There were no $N$-nitrosamines such as NDEA detected by SPE/GC-MS, which may be attributed to $\mathrm{UV}\left(\mathrm{UV}_{254 \mathrm{~nm}}+185 \mathrm{~nm}\right.$ VUV$)$ photolysis and enhanced formation of ${ }^{\circ} \mathrm{OH}$ radicals in the $\mathrm{O}_{3} /$ VUV system. Furthermore, the degradation pathways of DDC were proposed. The results suggested that the $\mathrm{O}_{3} / \mathrm{VUV}$ was very effective in the removal of DDC collector from mineral flotation wastewaters with low risk of $N$-nitrosamine formation.

\section{Conflicts of interest}

There are no conflicts to declare.

\section{Acknowledgements}

This work was supported by the National Natural Science Foundation of China (grant number: 51674017). The authors would greatly appreciate the Experiment Center in School of Metallurgical and Ecological Engineering, University of Science and Technology Beijing for providing the SPE/GC-MS analysis.

\section{References}

1 S. Kanchi, P. Singh and K. Bisetty, Arabian J. Chem., 2014, 7, 11-25.

2 L. Kloppers, W. Maree, O. Oyekola and G. Hangon, Miner. Eng., 2016, 87, 54-58.

3 J. Taguta, C. T. O'Connor and B. McFadzean, Miner. Eng., 2018, 119, 99-104.

4 X. P. Niu, R. M. Ruan, L. Y. Xia, L. Li, H. Y. Sun, Y. Jia and Q. Y. Tan, Langmuir, 2018, 34, 2716-2724.

5 D. R. Nagaraj and R. S. Farinato, Miner. Eng., 2016, 96-97, 214.

6 R. Kesari and V. K. Gupta, Talanta, 1998, 45, 1097-1102.

7 J. E. Poldoski, Environ. Sci. Technol., 1980, 14, 735.

8 M. Block and P. Pärt, Aquat. Toxicol., 1986, 8, 295-302.

9 A. Oskarsson and H. Tjalve, Arch. Toxicol., 1980, 45, 45-52.

10 J. Aaseth, J. Alexander and A. Wannag, Arch. Toxicol., 1981, 48, 29-39.

11 L. P. Padye, J. H. Kim and C. H. Huang, Water Res., 2013, 47, 725-736.

12 H. Mestankova, K. Schirmer, S. Canonica and U. von Gunten, Water Res., 2014, 66, 399-410.

13 H. Takeuchi, N. Yamashita, N. Nakada and H. Tanaka, Int. J. Environ. Res. Public Health, 2018, 15, 1-16.

14 W. F. Wang, J. Wang, Y. L. Guo, C. Y. Zhu, F. Pan, R. J. Wu and C. F. Wang, Sci. Total Environ., 2018, 639, 934-943.

15 C. Lee, C. Schmidt, J. Yoon and U. von Gunten, Environ. Sci. Technol., 2007, 41, 2056-2063.

16 B. McFadzean, D. G. Castelyn and C. T. O'Connor, Miner. Eng., 2012, 36-38, 211-218.

17 J. Taguta, C. T. O'Connor and B. McFadzean, Miner. Eng., 2017, 110, 145-152.

18 S. H. Chen, W. Q. Gong, G. J. Mei, Q. Zhou, C. P. Bai and N. Xu, Miner. Eng., 2011, 24, 953-955.
19 S. H. Chen, W. Q. Gong, G. J. Mei, L. Xiong and N. A. Xu, Int. J. Miner. Process., 2011, 101, 112-115.

20 P. F. Fu, X. F. Lin, G. Li, Z. H. Chen and H. Peng, Minerals, 2018, 8, 1-15.

21 B. Y. Cui, X. T. Wang, Q. Zhao and W. G. Liu, J. Chem., 2019, 7038015.

22 S. P. Mezyk, W. J. Cooper, K. P. Madden and D. M. Bartels, Environ. Sci. Technol., 2004, 38, 3161-3167.

23 B. B. Xu, Z. L. Chen, F. Qi, J. Ma and F. C. Wu, J. Hazard. Mater., 2009, 168, 108-114.

24 B. B. Xu, Z. L. Chen, F. Qi, J. Ma and F. C. Wu, J. Hazard. Mater., 2010, 179, 976-982.

25 M. G. Gonzalez, E. Oliveros, M. Wörner and M. A. Braum, J. Photochem. Photobiol., C, 2004, 5, 225-246.

26 P. F. Fu, J. Feng, H. F. Yang and T. W. Yang, Process Saf. Environ. Prot., 2016, 102, 64-70.

27 T. Ratpukdi, S. Siripattanakul and E. Khan, Water Res., 2010, 44, 3531-3543.

28 F. J. Beltran, F. J. Rivas and O. Gimeno, J. Chem. Technol. Biotechnol., 2005, 80, 973-984.

29 C. Lee, W. Choi, Y. G. Kim and J. Yoon, Environ. Sci. Technol., 2005, 39, 2101-2106.

30 M. H. Plumlee, M. López-Mesas, A. Heidlberger, K. P. Ishida and M. Reinhard, Water Res., 2008, 42, 347-355.

31 N. Quici, M. I. Litter, A. M. Braun and E. Oliveros, J. Photochem. Photobiol., A, 2008, 197, 306-312.

32 J. Swietlik, A. Dabrowska, U. Raczyk-Stanislawiak and J. Nawrocki, Water Res., 2004, 38, 547-558.

33 X. H. Chen, Y. H. Hu, H. Peng and X. F. Cao, J. Cent. South Univ., 2015, 22, 495-501.

34 W. X. Lin, J. Tian, J. Ren, P. T. Xu, Y. K. Dai, S. Y. Sun and C. Wu, Environ. Sci. Pollut. Res., 2016, 23, 785-792.

35 E. Silvester, D. Truccolo and F. P. Hao, J. Chem. Soc., Perkin Trans. 2, 2002, 1562-1571.

36 R. Q. Liu, W. Sun, K. Ouyang, L. M. Zhang and Y. H. Hu, Miner. Eng., 2015, 70, 222-227.

37 A. R. Bartholomaeus and V. S. Haritos, Food Chem. Toxicol., 2005, 43, 1687-1701.

38 W. Hugler, C. Acosta and S. Revah, Environ. Prog., 1999, 18, 173-177.

39 A. Aqeel, C. J. Kim and H. J. Lim, Int. J. Greenhouse Gas Control, 2017, 64, 194-203.

40 K. L. Aspila, V. S. Sastri and C. L. Chakrabarti, Talanta, 1969, 16, 1099-1102.

41 E. C. Tuazon, P. Martin, S. M. Aschmann, J. Arey and R. Atkinson, Int. J. Chem. Kinet., 2011, 43, 631-638.

42 I. Barnes, P. Wiesen and M. Gallus, J. Phys. Chem. A, 2016, 120, 8823-8829.

43 H. J. Fang, Q. Y. Bin, Y. Qin, W. B. Dong and H. Q. Hou, Chin. Sci. Bull., 2005, 50, 2832-2835.

44 C. Appaw and Y. G. Adewuyi, J. Hazard. Mater., 2002, 90, 237249.

45 L. Wang, D. Y. Wu, S. D. Wang and Q. Yuan, J. Environ. Sci., 2008, 20, 436-440.

46 A. Kotronarou, G. Mills and M. R. Hoffmann, Environ. Sci. Technol., 1992, 26, 2420-2428. 